\title{
DEMOKRASI DAN TANTANGANNYA DALAM BINGKAI PLURALISME DI INDONESIA
}

\section{Oleh: Syurya Muhammad Nur*}

\begin{abstract}
ABSTRAK
Artikel ini membahas tentang berlangsungnya demokrasi di Indonesia. Sebagai negara dengan penduduk muslim terbesar, bagaimana nilai-nilai Islam mempengaruhi berjalannya demokrasi di negara ini. Indonesia memiliki 1.331 kelompok suku dan 652 bahasa daerah. Dengan kemajemukan tersebut negara 'mengajarkan' tentang toleransi dan pluralisme melalui semboyan yang dikenal 'Bhineka Tunggal Ika', berbeda-beda namun tetap satu jua. Nilai-nilai demokrasi, agama, dan pluralisme juga terkandung dalam dasar negara, Pancasila. Meski begitu, demokrasi di Indonesia mengalami pasang surut. Tantangan terbesar saat ini adalah menguatnya politik identitas.
\end{abstract}

Kata Kunci: Demokrasi, Islam, Pluralisme

\begin{abstract}
This article discusses the ongoing democracy in Indonesia. As a country with the largest Muslim population, how do Islamic values affect the functioning of democracy in this country. Indonesian has 1,331 ethnic groups and 652 regional languages. With this diversity, the state 'teaches' about tolerance and pluralism through the motto known as 'Bhineka Tunggal Ika', unity in diversity. The values of democracy, religion, and pluralism are also contained in the foundation of the state, Pancasila. Even so, democracy in Indonesia experiences ups and downs. The biggest challenge now is intolerance and the strengthening of identity politics.
\end{abstract}

Keywords: Democracy, Islam, Pluralism

$\begin{array}{lllll}\text { *Dosen Fakultas Ilmu Komputer, } & \text { Universitas } & \text { Esa } & \text { Unggul. } \\ \text { Email:syurya.muhammadnur@esaunggul.ac.id }\end{array}$ 


\section{Pendahuluan}

Berdasarkan pemahaman kita secara sederhana selama ini demokrasi yaitu demos artinya rakyat, kratos artinya pemerintahan. Jadi demokrasi adalah pemerintahan yang rakyatnya memiliki peranan penting sebagai sumber kedaulatan negara. Menurut Muchtar (2006), Istilah demokrasi baru populer digunakan kembali setelah Revolusi Amerika dan Revolusi Perancis sebagai lawan dari sistem pemerintahan monarki mutlak yang menguasai dunia barat sebelumnya. Selanjutnya menurut Aidul (2005), Demokrasi pada masa Yunani kuno hanya sedikit memiliki atau bahkan tidak mempunyaigagasan mengenai hak dan kebebasan individual sebagaimana melekat dalam gagasan demokrasi modern. Di abad 21 ini demokrasitelah menjadi ideologi utama yang diterapkan di negara - negara maju sebagai sistem politik untuk menjalankan roda pemerintahan negaranya termasuk Indonesia.

Sebelum seperti sekarang, perjalanan demokrasi di Indonesia menurut Afan (1999), dibagi dalam empat periodesasi waktu yaitu masa revolusi pada awal kemerdekaan, demokrasi parlementer 1950-1959, demokrasi terpimpin 1959-1965, dan demokrasi Orde Baru tahun 19651998. Setiap periodesasi memiliki berbagai macam praktik demokrasi yang berbeda dalam sistem politiknya.

Richard (2004), Demokrasi sendiri menyerap pemikiran dan perilaku seluruh masyarakatnya. Sehingga pelaksanaan demokrasi memiliki karakteristik dan implementasi yang berbeda-beda di setiap negara. Berdasarkan data dari Ditjen Informasi dan Komunikasi Publik (2017), Indonesia dengan masyarakatnya yang mayoritas memeluk agama Islam (lebih dari 207 juta atau 87,2\%) menyumbang keragaman implementasi demokrasi tersebut. Agama menjadi salah satu variabel penting yang turut menentukan sebuah pentas politik, artinya nilai dasar agama menjadi kekuatan dalam politik di Indonesia. Sehingga secara langsung agama dapat mempengaruhi pergerakan dan cita rasa demokrasi di Indonesia.

Keberlangsungan demokrasi di negara dengan masyarakat 
mayoritas muslim di Indonesia sejauh ini dinilai positif oleh tokoh dunia pada forum-forum internasional. Misalnya oleh Koffi Anan, Sekretaris Jenderal PBB 1997 2006 ini mengatakan "Agama tidak mengajarkan membunuh sesama. Agama adalah bagian dari prinsip pluralisme," katanya. Semboyan Indonesia 'Bhinneka Tunggal Ika,' kata Kofi menjadi contoh bagi banyak negara di dunia, Republika (2016). Pluralisme lekat hubungannya dengan Bhineka Tunggal Eka, semboyan ini merupakan aksioma pluralisme dan toleransi sebagai keniscayaan dalam kehidupan politik berbangsa dan bernegara. Meski begitu, berjalannya demokrasi di Indonesia tidak serta merta berjalan mulus. Dari pemaparan di atas, penulis tertarik untuk mengulas lebih dalam tentang berjalannya dan keterkaitan antara politik identitas, demokrasi, islamdan pluralisme serta tantangannya di Indonesia.

\section{Metode}

Metode pengumpulan dan pengolahan data yang digunakan dalam kajian ini menggunakan studi pustaka (library research) sebagai bahan literatur yang dapat menyajikan data dan disertai dokumen pendukung yang menjadi referensi penting dalam kajian ini.

\section{Pembahasan.}

\section{Hubungan Agama dan Negara} dalam Islam.

Berdasarkan menurut bahasa sansekerta, kata agama dibagi dua yaitu " $a$ " tidak "gama" kacau, jadi agama adalah tidak kacau, secara pengertian agama adalah suatu peraturan untuk mengatur manusia dalam berkehidupan di dunia agar tidak kacau. Sedangkan Negara yaitu suatu organisasi kelompok masyarakat yang memiliki cita-cita sama dan hidup di suatu daerah tertentu yang memiliki pemerintahan berdaulat. Ada tiga tipologi hubungan antara agama dan negara. Tiga tipologi tersebut berdasarkan pemetaan oleh Din Syamsudin dalam Abu Zahra (1999 : 45) yang cukup populer dalam wacana kenegaraan Islam, sebagai berikut:

$$
\begin{aligned}
& \text { 1. Perspektif Integralistik: } \\
& \text { golongan yang berpendapat }
\end{aligned}
$$


bahwa hubungan antaraagama dan negara berjalan secara integral. Paradigma integralistik merupakan paham dan konsep hubungan negara dan agama yang menganggap bahwa negara dan agama merupakan satu kesatuan yang tidak dapat dipisahkan. Keduanya merupakan dua lembaga yang menyatu. Paradigma Intergralistik ini melahirkan konsep tentang agamanegara, yang berarti bahwa kehidupan kenegaraan diatur dengan menggunakan hukum dan prinsip keagamaan.

2. Perspektif Sekuleristik: golongan yang berpendapat bahwa hubungan antaraagama dan negara berjalan secara simbiotik dan dinamisdialektis, tidak berhubungan langsung. Kedua wilayah masih ada jarak dan kontrol masing-masing. Nurcholis Madjid menjelaskan bahwa saeculum sebenarnya adalah salah satu dari dua kata Latin yang berarti dunia. Kata lainnya adalah mundus. Tetapi saeculum memiliki arti kata waktu, sedangkan mundus sebagai kata ruang. Sedangkan lawan kata dari saeculum ialah eternum yang berarti abadi, kemudian digunakan untuk menunjukkan alam yang kekal abadi, yaitu alam sesudah dunia, Nurcholis (2013 : 21). Paham sekuler memisahkan dan membedakan antara negara dan agama secara diametral. Sedangkan agama adalah hubungan manusia dengan Tuhan dalam dimensi individual. Dua hal ini, tidak dapat disatukan menurut paham sekuler.

3. Perspektif Simbiotik: golongan yang berpendapat bahwa hubungan negara dan agama dipahami saling membutuhkan dan bersifat timbal balik. Teori simbiosis membiarkan tuntutantuntutan realitas sosial politik yang berkembang, lalu agama memberikan justifikasinya. 
Agama tak harus menjadi dasar negara. Negara hanya menjadi wilayah yang mandiri. Menurut Rijal (2010), Intervensi agama adalah dalam wilayah ketika negara dianggap telah menyimpang dari normanorma agama.

Menurut Abdul (2013 : 279) Mengenai hubungan agama dan negara, Islam sejak awal tidak memberikan ketentuan yang pasti tentang bagaimana konsep dan bentuk negara yang dikehendaki. Dalam konsep Islam, dengan mengacu pada al-Quran dan alHadist, tidak ditemukan rumusan tentang negara secara eksplisit, hanya di dalam kedua sumber hukumIslam itu terdapat prinsip-prinsip dasar dalam bermasyarakat, berbangsa dan bernegara, diantaranya adalah:

1. Keadilan (QS. 5:8) yang artinya "Berlaku adillah kalian karena adil itu lebih dekat kepada taqwa". Keadilan merupakan nilainilai kemanusiaan yang asasi dan menjadi pilar dalam berbagai aspek kehidupan, baik individu, keluarga maupun masya-rakat. Negara menurut Muhammad Natsir dalam Indah Muliati (2015) harus dibangun atas dasar keadilan. Menurut Natsir, keadilan yang dibawa oleh Islam, baik dibidang hukum, sosial maupun ekonomiadalah keadilan yang menempatkan manusia sebagai makhluk yang berdaulat dan bermartabat.

2. Musyawarah (QS. 42:38) yang artinya "dan (bagi) orang-orang yang menerima (mematuhi) seruan Tuhandan melaksanakan salat, sedang urusan mereka (diputuskan) dengan musyawarah antara mereka; dan mereka menginfakkan sebagian dari rezeki yang Kami berikan kepada mereka”. Musyawarah atau dalam Islam dikenal dengan syura adalah sebuah proses dialogis yang dilakukan di antara kelompokkelompok sosial yang ada di tengah 


\section{JURNAL ILMIAH MIMBAR DEMOKRASI}

masyarakat. Menurut Heri (2019 : 46), Prinsip syura di antara kaum muslimin dalam menyelenggarakan kekuasaan politik pemerintahan ini menunjukan sebuah prinsip demokrasi bahwa kekuasaan akan selalu

dipertanggungjawabkan

kepada rakyat dan Tuhan.

Rakyat yang telah memilih melalui mekanisme musyawarah, pertanggung jawaban kepada Allah selaku penguasa multak..

3. Menegakkan kebaikan dan mencegah kemungkaran (QS. 3:110) yang artinya "Катu adalah umat yang terbaik yang dilahirkan untuk manusia, menyuruh kepada yang ma'ruf dan mencegah dari yang munkar, dan berimanlah kepada Allah". Pemimpin atau dalam Islam disebut khalifah hendaknya selalu menegakkan kebaikan dan mencegah kemungkaran. Begitupun dalam bermasyarakat. Supaya tetap terjaga kerukunan antarumat.
4. Perdamaian dan persaudaraan (QS. 49:10) yang artinya "Sesungguhnya orang-orang yantog beriman adalah bersaudara karena itu damaikanlah antara kedua saudaramu dan bertaqkwalah kepada Allah supaya kamu mendapat rahmat". Masalah kemanusiaan harus menjadi pijakan bersama umat dalam membangun bangsa. Meskipun berbeda-beda semua masyarakat hendaknya menjaga tali persaudaraan tanpa melihat suku, agama, dan ras. Supaya menciptakan suasana toleransi dan perdamaian antar umat manusia.

5. Keamanan (QS. 2:126) yang artinya "Dan ingatlah ketika Ibrahim berdo'a, Ya Tuhanku jadikanlah negeri ini negeri yang aman sentosa”. Dalam bermasyarakat dan bernegara keamanan menjadi idaman bersama. Lingkungan atau negara hendaknya menciptakan rasa aman bagi warganya. 
6. Persamaan (QS. 16:97) yang artinya "Barang siapa yang mengerjakan amal saleh, baik laki-laki maupun perempuan dalam keadaan beriman, maka sesungguhnya akan Kami berikan kepadanya kehidupan yang baik". Persamaan mengandung pengertian tidak membeda- bedakan siapapun dalam mentaati undangundang, tidak ada yang lebih tinggi dari yang lain. Sehingga, antara penguasa dan rakyat mempunyai kedudukan yang sama, tidak ada keistimewaan di depan hukum. Heri (2019 : 136) menyatakan persamaan merupakan suatu prinsip yang tidak memandang seseorang berdasarkan pertimbangan ras, suku, silsilah maupun fanatisme.

\section{Semangat Pluralisme melalui} Bhineka Tunggal Ika.

Menurut Nurcholis Madjid dalam Azyumardi Azra (2001 : 27), pluralisme merupakan pertalian sejati kebhinekaan dalam ikatan-ikatan keadaban. Bahkan pluralisme merupakan seuatu keharusan bagi keselamatan umat manusia melalui mekanisme pengawasan dan pengimbangan (check and balance). Lebih lanjut Nurcholis Madjid mengatakan bahwa sikap penuh pengertian kepada orang lain sangat diperlukan dalam konteks masyarakat majemuk.

Dengan demikian maka, pemahaman pluralisme sangat di butuhkan bagi Indonesia sebagai penggiring sistem demokrasi, sehingga sistem demokrasi di Indonesia bisa berjalan dengan lancar dan masyarakat hidup berdampingan dengan damai dalam satu sistemyaitu demokrasi, satu ideologi yaitu pancasila dan satu semboyan yaitu Bhineka Tunggal Ika (berbeda-beda namun satu jua).

Menurut Said (2005 : viii), Kemajemukan masyarakat Indonesia ditandai oleh berbagai perbedaan baik horizontal maupun vertikal. Perbedaan horizontal meliputi kesatuan-kesatuan sosial berdasarkan suku bangsa, bahasa, dan adatistiadat. Sedangkan perbedaan yang 
bersifat vertikal yakni menyangkut hubungan manusia dengan penciptanya yang dalam hal ini adalah keragamaan agama yang diakui di Indonesia seperti Islam, Kristen, Budha, Hindu dan Katholik. Masyarakat Indonesia juga merupakan masyarakat plural (Zainuddin, 2010 : 1).

Pluralisme menjadi salah satu tolok ukur, apakah bangsa tersebut berhasil menegakan nilai-nilai pluralis seperti toleransi dan kesetaraan atau hanya sekedar jargon saja ?. Namun demikian, menurut Nawawi (2014 : 441) pluralisme ternyata bukan sesuatu yang mudah diterima khususnya di negara-negara yang memiliki tingkat kolektifitasdan homogenitas yang tinggi. Hal ini diperkuat oleh data dari Ditjen Informasi dan Komunikasi Publik (2010) Indonesia yang memiliki 1.331 kelompok suku dan 652 bahasa daerah. Maka, pluralisme dalam negara tercantum di dalam Pancasila yang merupakan pandangan hidup bangsa Indonesia dan sekaligus merupakan dasar negara Indonesia. Sebagai pandangan hidup, nilai-nilai luhur yang dikandungnya merupakan pedoman dan tuntunan dalam setiap pola tingkah laku dan pola pikir bangsa Indonesia.

Dalam sejarahnya, Pancasila yang terdiri dari lima sila dapat dicari titik temunya dengan norma agama, tidak hanya sesuai dengan norma agama Islam, tetapi juga dengan norma agama lainnya. Sila pertama, Ketuhanan Yang Maha Esa, yang mengambarkan bahwa Tuhan adalah Dzat Yang Esa. Sila pertama juga pernah dijadikan tujuan pertama dalam pendidikan keagamaan Nabi Muhammad SAW ketika berada di Makkah dengan berusaha agar seluruh umat manusia menyembah Tuhan Yang Maha Esa. Sila kedua, Kemanusiaan yang adil dan beradab menggambarkan bahwa setiap tindakan manusia harus berasal dari akal sehat dan hati nuraninya.Melalui pendidikan diharapkan akan meningkatkan keimanan dan ketaqwaan serta pembinaan akhlakul karimah sebagaimana dinyatakan pada Pasal 31 ayat (3) dan Nabi Muhammad SAW juga diutus untuk membina akhlakul karimah, disamping menegakkan hukum secara adil. Sila ketiga, Persatuan 
Indonesia menjadi faktor penentu dalam melindungi segenap bangsa, memajukan kesejahteraan umum dan mencerdaskan kehidupan bangsa serta mewujudkan perdamaian dunia yang abadi sebagaimana juga telah dipraktikkan Nabi Muhammad SAW di Madinah ketika membangun negara Madinah. Nabi Muhammad SAW membangun persatuan dan kesatuan dalam masyarakat yang majemuk. Sila keempat, Kerakyatan yang dipimpin oleh hikmat kebijaksanaan dalam permusyawaratan/perwakilan.

Prinsip sila ini hendak mengembangkan kearifan dan kebijaksanaan dalam bermusyawarah. Dalam sistem musyawarah tersebut, ada empat prinsip yang hendak dikembangkan, yaitu rasionalisme, kepentingan umum, kepentingan jangka panjang dan memperhatikan semua golongan. Salah satu contohnya adalah penyusunan naskah Perjanjian Hudaibiyah, dimana Nabi Muhammad SAW menyusunnya melalui proses musyawarah dengan melibatkan kelompok non-Muslim. Sila kelima, Keadilan Sosial bagi
Seluruh Rakyat Indonesia. Menurut Dahlan (2014 : 18), Sila ini merupakan perwujudan nyata dari semua sila. Prinsip keadilan sosial dapat menjadi pelindung bagi seluruh warga negara. Pada zaman Nabi Muhammad SAW juga diperintahkan oleh Allah SWT untuk berbuat adil dan mewujudkan kemaslahatan umum.

Kehidupan pluralisme pada hakikatnya memerlukan rasa menerima keragaman budaya yang amat tinggi. Tidak hanya toleransi yang dibutuhkan dalam kehidupan pluralisme, memahami dan mengerti perbedaan itu seharusnya menjadi awal dalam menjalani hubungan dengan komunitas yang berbeda baik secara budaya maupun secara politis. Untuk itulah pada hakikatnya untuk memiliki sikap toleransi tergantung sikap dari semua pihak untuk menurunkan tensi egonya, agar kerukunan yang dicita-citakan berdasarkan Pancasila yaitu "Persatuan Indonesia" akan tercapai tanpa ada proses yang tidak berkeadilan. 


\section{Politik Identitas menjadi}

\section{Tantangan Demokrasi di}

\section{Indonesia.}

$\begin{array}{lcc}\text { Demokrasi di } & \text { Indonesia } & \text { telah } \\ \text { memasuki } & \text { tahun } & \text { ke-20 }\end{array}$ pascareformasi. Menurut laporan The Economist Intelligence Unit yang meneliti tingkat kebebasan di 167 negara, rangking demokrasi Indonesia turun 20 peringkat dari posisi 48 ke peringkat 68 (IDI : 2018). The Economist menggunakan lima kategori untuk menentukan peringkat demokrasi yang mencakup proses elektoral dan pluralisme, kebebasan sipil, fungsi pemerintahan, partisipasi politik, dan kultur politik. Politik identitas di Indonesia bukanlah hal yang baru. Setelah kemerdekaannya, politik identitas berdasarkan etnis, suku, agama dan wilayah, yang disebut sentimen primordialisme olehGeertz, masih ada. Gerakan-gerakan yang bertujuan untuk memisahkan diri dari Indonesia yang muncul pada awal masa paska kemerdekaan didasarkan pada politik identitas itu. Di era Orde Baru, politik identitasditekan bersama dengan kebijakan tentang keamanan represif dan kebangkitan pemerintahan otoriter. Dalam pasca reformasi, dengan munculnya era kebebasan, ini adalah angin segar dalam perkembangan demokrasi yang telah ditangguhkan di era Orde Baru, tetapi di sisi lain, tuntutan dan konflik berdasarkan identitas politik muncul. Menurut Romli (2019 : 2) Dalam tiga tahun terakhir, kejadian paling menyita perhatian adalah saat pemilihan gubernur di Jakarta pada tahun 2017 dan berlanjut ke Pemilihan Kepala Daerah Serentak pada tahun 2018, mereka penuh dengan politik identitas dan politisasi SARA. Seperti yang kita ketahui pemilihan gubernur di Jakarta 2017 menjadi perhatian publik, itu terjadi karena ada beberapa demonstrasi yang menuntut agar Gubernur Jakarta, Basuki Tjahaja Purnama, atau dipanggil Ahok, diadili karena pidatonya di Pulau Seribu yang dianggap sebagai pelecehan terhadap Islam. Salah satu demonstrasi terbesar adalah Gerakan Pembela Islam 212 (diambil dari tanggal demonstrasi yaitu 2 Desember 2016). Berangkat dari situ, Burhanuddin Mukhtadi bersama 
Lembaga Survey Indonesia (2018) merilis hasil survey mengenai isu-isu intoleransi dan politik identitas yang menjadi rapor merah demokrasi Indonesia. Dalam studi ini, intoleransi dioperasionalkan dalam pertanyaan tentang apakah seorang muslim (atau nonmuslim) merasa keberatan atau tidak, jika nonmuslim (atau muslim) melakukan kegiatan peribadatan atau menjadi pemimpin pemerintahan pada berbagai tingkat. Dengan demikian,intoleransi dikategorikan ke dua dimensi, yakni intoleransi religius kultural dan intoleransi politik. Intoleransi religius kulturalmencakup seberapa keberatan responden muslim (atau nonmuslim) jika ada pemeluk agama lain membangun rumah ibadah atau melakukan kegiatan keagamaan. Sementara itu, intoleransi politik mengukur seberapa besar resistansi responden jika pemeluk agama lain menjadi presiden, wakil presiden, gubernur, bupati, atau wali kota. Untuk memberikan gambaran utuh, akan disajikan data multitahun untuk mengetahui tren tingkat intoleransi berdasarkan data survei 2010-2018.
Studi ini menemukan bahwa warga muslim cenderung intoleran kepada nonmuslim, terutama dalam hal politik. Pada 2018, sebanyak59\% responden muslim keberatan nonmuslim menjadi presiden; 55\% keberatan nonmuslim menjadi wapres; 52\% keberatan nonmuslim menjadi gubernur, bupati, atau wali kota. Data kami menunjukkan bahwa dalam dua tahun terakhir, terutama sejak aksi 212 pada 2016, intoleransi warga secara politik menunjukkan tren meningkat. Warga muslim keberatan jika nonmuslim menjadi pemimpin pemerintahan pada berbagai tingkat.

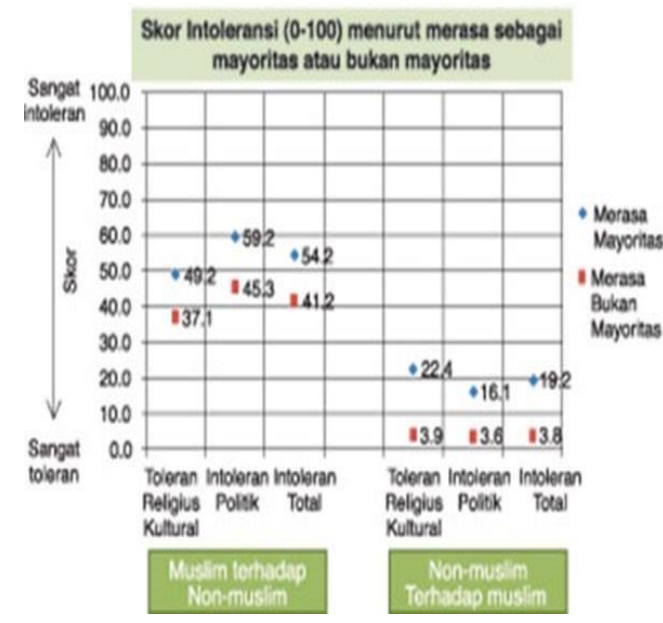

Grafik 1

Sumber: Lembaga Survey Indonesia Survey di atas menurut Burhan, bahwa secara umum 


\section{JURNAL ILMIAH MIMBAR DEMOKRASI}

12

nonmuslim memiliki intoleransi yang lebih rendah jika dibandingkan dengan muslim. Mereka lebihbanyak yang merasa tidak keberatan dengan kegiatan keagamaan muslim dan peran muslim sebagai pemimpin pemerintahan. Akan tetapi, perbedaan intoleransi pada muslim dan nonmuslim ini tidak berlaku umum. Pada situasi ketika muslim ataupun nonmuslim sebagai kelompok mayoritas di wilayah mereka, baik muslim maupun nonmuslim cenderung lebih intoleran jika dibandingkan dengan ketika mereka sebagai minoritas. Hal ini menunjukkan bahwa intoleransi bukan semata-mata disebabkanfaktor agama. Status sebagai kelompok yang lebih besar dan merasa berhak

menuntut keistimewaan tertentu (majority privilege) ikut memengaruhi intoleransi (Burhan, 2018).

Aksi 212 misalnya, mendapatkan dukungan luas dari mayoritas muslim di Indonesia.meski begitu, aksi 212 bukanlahpuncak dari radikalisme dan intoleransi seperti yang diduga banyak ahli. Sebelum aksi-aksi tersebut digelar, tren intoleransi dan radikalisme di kalangan kaummuslim Indonesia justru mengalami penurunan. Data survei menunjukkan bahwa aksi-aksi yang masif tersebut justru menaikkan tren intoleransi, padahal kecenderungan intoleransi sebelum aksi tersebut malahmenurun (Mietzner dan Muhtadi, 2018). Hal ini membantah argumen banyak pengamat yang mengatakan bahwa dampak aksi 212 hanyalah bersifat jangka pendek. Namun, ia juga memiliki implikasi politik elektoral yang serius. Naiknya politikidentitas dalam diskursus politik nasional dan lokal saat ini tak bisa dilepaskan dari keberhasilan aktor- aktor utama aksi 212 dalam mengampanyekan agendanya.

Selain berdampak pada Pemilihan Kepala Daerah Serentan (Pilkada) 2017, efek intoleransi dan penguatan politik identitas ini juga tampak pada Pemilihan Presiden, DPR, DPD, dan DPRD pada 2019. Pada pemilihan presiden misalnya, sentimen keagamaan hadir sejak awal pemilihan calon presiden oleh dua kandidat yaitu Joko Widodo (petahana) dan Prabowo Subianto 
(menantang). Joko Widodo atau dikenal dengan Jokowi memilih KH. Ma'ruf Amin sebagai wakilnya. Ia adalah Rais Aam Pengurus Besar Nadratul Ulama/PBNU (organisasi masa keagamaan terbesar di Indonesia) sekaligus Ketua Majelis Ulama Indonesia/MUI (MUImemiliki peran penting dalam kasus penistaan agama oleh Ahok dan aksi 212). Sedangkan Prabowo tidak memilih kandidat wakil presidennya dari saran Ijtima Ulama. Sebaliknya, ia memilih Wakil Gubernur DKI Jakarta, Sandiaga Uno, seorang pengusaha dan politisi Gerindra sebagai calon wakil presiden sehari sebelum pendaftaran calon presiden dan wakil presiden ditutup. Dengan tidak mengikuti rekomendasi IjtimaUlama I, GNPF kemudian menahan Ijtima Ulama II pada 16 September 2018. Kandidat Presiden, Prabowo Subianto, menandatangani 17 poin pakta integritas sebagai hasil dari Ijtima Ulama II.

Jika betul dilakukan, tentu hal ini penuh kontroversi. Selanjutnya, selama aksi kampanye pun tidaklepas dari atribut identitas agama danetnik. Berdasarkan berita $\mathrm{CNN}$
(2018), Misalnya saat Amien Rais (salah satu petinggi Partai Amanat Nasional) mengatakan saat khutbahdi Jakarta Selatan tentang Partai Allah dan Partai Setan. Khotbah itu menuai begitu banyak keluhan dari banyak kelompok, bahkan ada yang rela melaporkannya ke Polda Metro Jaya karena isinya membawa agama ke persaingan politik dan memancing sentimen SARA.

Kekhawatiran politik identitas juga dapat dilihat dari demonstrasi terkait pembakaran "Bendera Tauhid di Garut, JawaBarat, oleh individu Banser di Hari Peringatan Santri". Dari berita BBC yang dirilis pada 2018, Pembakaran itu dimaksudkan sebagai protes kepada HTI, sebuah organisasi yang dilarang oleh pemerintah karena mereka menentang ideologi Pancasila dan bertujuan untuk mendirikan negara Islam (Khilafah) yang memiliki bendera yang sama. Namun para pengunjuk rasa mengatakan bahwa bendera itu adalah bendera Rasullah.

Meski begitu, jika kita lihat survei publik yang dilakukan oleh Pusat Penelitian Politik 2018, 
kepercayaan masyarakat Indonesia terhadap demokrasi cukup tinggi, yaitu $73 \%$ (setuju $65 \%$ dan sangat setuju 8\%). Jadi, sebagian besar orang Indonesia percaya pada demokrasi sebagai sistem pemerintahan yang lebih baik dibandingkan dengan sistem lain. Kepercayaan publik akan terganggu ketika elit politik dan aktor demokrasi tidak menggunakan demokrasi sebagai satu-satunya aturan. Keberadaan politik identitas oleh politisasi SARA yang berkembang di masyarakat berpotensi menghambat konsolidasi demokrasi. Ini telah dikonfirmasi dari survei ahli yang dilakukan oleh Pusat Penelitian Politik LIPI (Lembaga Ilmu Pengetahuan Indonesia).

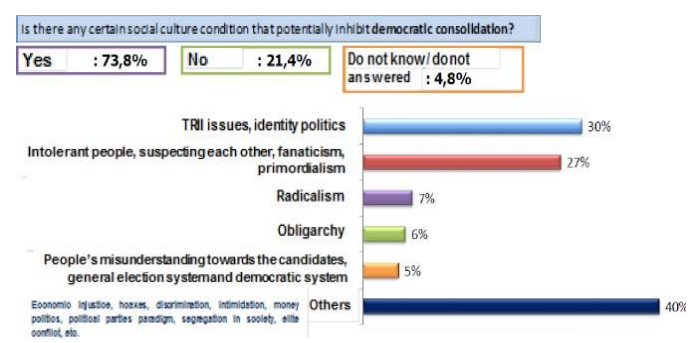

\section{Grafik 2}

Sumber: Presentation of National Priority Expert Survey Team Political, Economy, Social Culture, Defense and Security Condition Mapping Approaching the
Simultaneous General Election 2019

(Lili Romli, 2019).

Survei ahli mengatakan bahwa ada $73,8 \%$ menghambat budaya sosial. Dari jumlah itu, 30\% berasal dari masalah TRRI dan politik identitas, $27 \%$ dari orangorang tidak toleran, saling curiga, fanatisme dan primordialisme, dan 7\% dari gerakan radikalisme. Untuk mengatasi faktor-faktor tersebut, para ahli menyarankan solusi dengan mensosialisasikan nilai-nilai ke Indonesia, gerakan perdamaian, pendidikan politik, contoh elit dan reformasi partai politik.

Masa depan demokrasi di Indonesia tidak akan terlepas dari islam dan demokrasi itu sendiri. sementara beberapa konservatif dan bahkan akademisi masih mempertanyakan penerapan islam untuk demokrasi, ada banyak varian yang mendukung koeksistensi islam dan demokrasi, seperti yang disampaikan Muhammad Natsir dalam tulisannya theistik democracy, demokrasi islam, dll. Menurut Wildan (2016 : 4), Mereka secara sinis dan curiga mengklaim bahwa di atas koeksistensi sebagai contradicio 
in terminis. Banyak kaumkonservatif mencurigai demokrasi sebagai nilai barat yang tidak cocok untuk masyarakat Islam, sedangkanbanyak sarjana mempertanyakan bagaimana hak minoritas dapat dipenuhi begitu norma-norma agama tertentu menjadi dasar negara.

Indonesia adalah kumpulan identitas yang menyatu dalam sebuah manifesto politik Sumpah Pemuda. Nilai Sumpah Memuda merupakan manifestasi dan pengakuan putraputri untuk hidup bersama dalam naungan keindonesiaan. Meleburkan identitas diri menjadi identitas kebersamaan. Konkritnya, kebersamaan untuk menjadi satu bangsa bernama Indonesia. Spirit Sumpah Pemuda ini ditemukan pula pada nilai-nilai luhur Pancasila. Pancasila adalah lambang pemersatu dari semua identitas subjektif, hingga aliran, dan ideologi. Menurut Laode (2018 : v) Kompleksitas identitas diri tidak hanya diwujudkan melalui kategori-kategori sosial. Tetapi identitas diri juga bisa masuk kategori politis apabila disangkutkan dengan afiliasi partai politik, politisasi identitas, dan meniupkan
SARA kepada kelompok lain atau lawan-lawan politik dalam bingkai perebutan kekuasaan. Politikidentitas bukan hanya akan mengurangi kesempatan pemilih untuk mendapatkan kampanye yang bermutu dan kredibel, melainkan juga membahayakan tenun kebangsaan yang telah dijahit dengan benang-benang keberagamaan dan kemajemukan.

\section{Kesimpulan.}

Dari paparan di atas maka dapat disimpukan bahwa demokrasi dan Islam di Indonesia tak bisa lepas dan akan hidup berdampingan. Nilai-nilai pluralisme yang digaungkan sejak pendirian negara ini kembali menjadi topik yang digunakan untuk rekonsiliasi politik. Akibat memanaskannya suasana politik dalam tiga tahun terakhir. Salah satu penyebabnya adalah gerakan 212 yang menciptakan tren intoleransi meningkat, sekaligus menjadi highlight penurunan angka indeks demokrasi Indonesia menurut The Economist (2018). Hal ini tampak pada menguatnya isu SARA pada Pilkada serentak 2017, dan 
Pemilihan Presiden sekaligus DPR, DPD, dan DPRD pada 2019.

$$
\text { Masa depan demokrasi }
$$

Indonesia berada dalam kerentanan dan tantangan serius dengan menguatnya intoleransi dan politik identitas. Politik identitas tidak hanya ancaman terhadap pluralisme dan demokrasi, tetapi juga ancaman serius terhadap Indonesia yang didasarkan pada keanekaragaman. Maka, nilainilai pluralisme, BhinekaTungga Ika, dan semangat Pancasila perlu digaungkan lagi.

\section{DAFTAR PUSTAKA.}

\section{Buku.}

Abu Zahra (ed.), 1999. Politik Demi Tuhan; Nasionalisme Religius di Indonesia. Bandung: Pustaka Hidayah

Afan Gaffar. 1999. Politik Indonesia: Transisi Menuju Demokrasi. Pustaka Pelajar: Jakarta.

Aidul Fitriciada Azhari. 2005. Menemukan demokrasi. Muhammadiyah University Press: Surakarta.

Azyumardi Azra. 2001. Menuju Masyarakat Madani. Bandung : PT Remaja Rosdakarya.

Burhanuddin Muhtadi. 2013. 'Potret Islam Pasca Orde Baru" in Jefrie Geovanie, civil religion: dimensi sosial politik Islam. Jakarta: Gramedia

Herdiawanto, Heri. Wasitaatmadja, Fokky, Hamdayama, Jumanta. 2019. Kewarganegaraan \& Masyarakat Madani. Prenadamedia Group: Jakarta.

Laode Machdani Afala. 2018. Politik Identitas di Indonesia. Malang: Tim UB Press

M. Zainuddin.2010. Pluralisme Agama : Pergulatan Dialogis Islam-Kristen di Indonesia. Malang: UIN-Maliki Press.

Muchtar Pakpahan. 2006. Ilmu Negara dan Politik. Penerbit PT Bumi Intitama Sejahtera: Jakarta.

Nurcholis Madjid. 2013. Islam Kemodernan dan KeIndonesiaan. Penerbit MizanPustaka: Jakarta.

Richard M. Kettchum (Ed). 2004. Demokrasi Sebuah Pengantar. Penerbit Niagara: Yogyakarta.

Said Agil Husin Al Munawar. 2005. Fikih Hubungan Antar Agama, Jakarta: Ciputat Press.

\section{Jurnal.}

Abd. Salam Arif. 20013. Hubungan Agama dan Negara dalam Perspektif Islam. Jurnal Kajian Islam Interdisipliner Vol.2 No. 2 JuliDesember 2003:278-287.

$$
\text { Indah Muliati. } 2015 .
$$

Pandangan M. Natsir Tentang Demokrasi: Kajian Pemikiran Politik Islam. Jurnal Tingkap Universitas Negeri Padang Vol. XI No. 2 Th. 2015. 
Lili Romli. 2019. Political Identity and Challenges for Democracy Consolidation in Indonesia. Politik Indonesia: Indonesian Political Science Review 4 (1), January 2019, pp.78-98 ISSN 2477-8060 (print), ISSN 2503-4456

Moh. Dahlan. 2014. Hubungan Agama dan Negara di Indonesia. Jurnal Studi Keislaman, Volume 14, Nomor 1, Juni 2014.

Muhammad Nawawi. 2014. Pluralisme dalam Bingkai Islam dan Negara. IN RIGHT Jurnal Agama dan Hak Azazi Manusia Vol. 3, No. 2, Mei 2014

Muhammad Wildan. 2016. Islamism and Democratization in the Post 411 and 212 Rallies of Indonesia. Journal of Thinking ASEAN From Southest Asia forSouthers Asia Issue 19, January 2016.

\section{Media.}

BBC Indonesia. 2018. Bagaimana pembakaran 'bendera HTI' itu jadi 'pembakaran bendera tauhid'?. Diakses melalui https://www.bbc.com/indonesia/indo nesia-45951832 pada 29 Juli 2019

Burhanuddin Mukhtadi. 2018. Menguatnya Intoleransi dan Politik Identitas. Dimuat dalam
Koran Media Indonesia edisi 20 Desember 2018 dan secara online dapat diakses melalui https://mediaindonesia.com/read/deta il/205379-menguatnya-intoleransidan-politik-identitas

CNN Indonesia. 2018. Polda Metro Jaya Akan Periksa Amien Rais Soal Partai Setan. Diakses melalui

https://www.cnnindonesia.com/nasio nal/20180503191222-12-

295527/polda-metro-jaya-akanperiksa-amien-rais-soal-partai-setan pada 29 Juli 2019

Ditjen Informasi dan Komunikasi Publik. 2017. Agama Penduduk Indonesia. Diakses melalui https://www.indonesia.go.id/profil/ag ama pada 26 Juli 2019.

Republika, 2016. Islam dan Demokrasi di Indonesia Jadi Aset Dunia. Diakses melalui https://www.republika.co.id/berita/na sional/umum/16/12/08/ohupuq359islam-dan-demokrasi-di-indonesiajadi-aset-dunia pada 27 Juli 2019.

The Economist. Indonesia Democracy Index 2018. Diakses melalui https://www.eiu.com/topic/democrac y-index pada 28 Juli 2019. 